\title{
PENDUGAAN MODEL LUAS DAUN TANAMAN PAKCOY (Brassica rapa L.) DENGAN REGRESI KUANTIL
}

\section{Leaf Area Estimation Model of Pakcoy (Brassica rapa L.) using Quantile Regression}

\author{
Riza Yuli Rusdiana ${ }^{1 *}$, Laily Ilman Widuri ${ }^{1}$ dan Didik Pudji Restanto ${ }^{2}$ \\ ${ }^{1}$ Program Studi Agronomi, Fakultas Pertanian, Universitas Jember, \\ ${ }^{2}$ Program Studi Magister Agronomi, Fakultas Pertanian, Universitas Jember, \\ Jalan Kalimantan 37 Tegalboto, Jember 68121, Indonesia \\ *Alamat korespondensi: rizayr@unej.ac.id
}

\begin{abstract}
ABSTRAK
Luas daun merupakan salah satu parameter penting untuk menentukan produksi pakcoy (Brassica rapa $\mathrm{L}$ ). Pengukuran luas daun secara non-destruktif salah satunya dapat dilakukan dengan pendekatan model persamaan matematika melalui regresi kuantil. Penelitian ini bertujuan untuk menduga model luas daun pakcoy dengan faktor alometrik dan pendekatan non-destruktif menggunakan regresi kuantil. Metode penelitian dilaksanakan dengan mengumpulkan data sampel daun diperoleh dari tanaman pakcoy secara acak dari berbagai level kanopi tanaman pakcoy (lower, middle dan upper) dengan jumlah sampel sebanyak 163 daun. Variabel pengamatan dalam penelitian adalah lebar, panjang dan luas daun pakcoy. Metode pendugaan model luas daun dilakukan dengan pendekatan regresi OLS dan kuantil. Hasil penelitian menunjukkan bahwa model regresi kuantil dapat direkomendasikan untuk menduga luas daun pakcoy secara non destruksi dan cepat dengan ketepatan akurasi tinggi. Model yang dapat direkomendasikan untuk menduga luas daun pakcoy secara non-destruksi, sederhana, dan akurat yakni $\mathrm{LA}_{0,5}=0,393+0,705 \mathrm{LW}$.
\end{abstract}

Kata kunci: kuantil, luas daun, non-destruksi, pakcoy, regresi

\section{ABSTRACT}

Leaf area is one of the important parameters to determine the production of pakcoy (Brassica rapa L.). Non-destructive measurement of leaf area can be done by approaching mathematical equation models using kuantil regression. This research aims to estimate the leaf area model of pakcoy with allometric factors and nondestructive approach using quantile regression. The research method was conducted by collecting leaf sample data which obtained from pakcoy plants randomly with various canopy level (lower, middle and upper) as many as 163 samples. The observation variables were width, length, and area of pakcoy leaves. The method of leaf area model estimation is carried out with an OLS and quantile regression approach. The results showed that quantile regression models can predict the area of pakcoy leaves on a non-destructive, rapid, and high accuracy. Recommended model for leaf area estimation of pakcoy leaf is $L A_{0.5}=0.393+0.705 \mathrm{LW}$.

Keywords: leaf area, non-destructive, pakcoy, quantile, regression

\section{PENDAHULUAN}

Brassica rapa L. yang biasa dikenal dengan nama pakcoy termasuk jenis tanaman sayuran penting di Asia. Tanaman ini merupakan varietas sawi yang dimanfaatkan daunnya. Daun-daun tersusun spiral rapat, tumbuh relatif tegak atau semi mendatar dan berbentuk cenderung oval. Pakcoy memiliki daun berwarna hijau tua dan tangkai daun berwarna putih atau hijau muda. Tangkai daun melekat pada batang yang tertekan dan berdaging atau tebal. Tinggi tanaman pakcoy berkisar antara 15$30 \mathrm{~cm}$ dan dapat beradaptasi pada daerah dataran rendah maupun dataran tinggi (Rubatzky \& Yamaguchi, 1997). Pakcoy merupakan salah satu tanaman sayuran daun berumur pendek dengan masa panen 
semusim atau satu kali panen dan memiliki nilai ekonomis tinggi karena banyaknya peminat. Masyarakat menggemari pakcoy dikarenakan rasa yang lezat dan mudah diolah. Kegiatan budidaya tanaman pakcoy telah banyak dilakukan baik secara konvensional (Andreeilee et al., 2014), hidroponik (Wibowo \& Asriyanti, 2013; Rizal, 2017; Santoso et al., 2020) maupun aquaponik (Astuti \& Larasati, 2019; Rahmadhani et al., 2020).

Pada kegiatan budidaya pakcoy, daun merupakan salah satu parameter penting untuk menentukan produksi tanaman pakcoy. Pengukuran nilai luas daun dapat dikembangkan untuk pengukuran indeks luas daun atau leaf area index (LAI) yang merupakan salah satu parameter penting untuk menunjukkan karakter pertumbuhan suatu tanaman (Sobari et al., 2018). Selain itu, indeks luas daun dapat mengukur tingkat fotosintesis, respirasi dan transpirasi serta memantau laju ekspansi daun selama pengembangan daun atau dalam menggambarkan kondisi stress lingkungan terutama karena kekurangan nutrisi dan air (Lakitan et al., 2017). Terdapat beberapa teknik pengukuran luas daun, yaitu dilakukan dengan memetik daun (destruksi) dan tanpa memetik daun (non destruksi). Pengukuran luas daun menggunakan teknik non destruksi lebih disarankan karena tidak merusak tanaman dan mendapatkan hasil yang cepat tanpa penggunaan alat.
Kecepatan dan ketepatan pengukuran luas daun diperlukan untuk mendapatkan hasil yang akurat (Irwan \& Wicaksono, 2017).

Berbagai macam teknik pengukuran luas daun secara non destruksi telah banyak dilakukan dan berkembang pesat, diantaranya menggunakan alat pengukur luas daun (leaf area meter) atau program komputer, laser scanner, hingga cover photography (Sadik et al., 2011; Kaur et al., 2014; Yan et al., 2019). Penelitian Sadik et al. (2011) menjelaskan bahwa hasil pengukuran luas daun dengan menggunakan program komputer, leaf area meter, maupun metode gravimetri menunjukkan tidak ada perbedaan signifikan. Pendugaan luas daun dengan menggunakan program komputer dinilai lebih direkomendasikan dari segi keakuratannya. Namun demikian, dalam implementasinya di lapangan, penggunaan alat-alat modern cenderung kurang praktis dan fleksibel, memerlukan keahlian spesifik dan biaya tinggi. Berdasarkan uraian tersebut, pendugaan luas daun tanaman secara non destruksi seperti pendekatan model matematis dinilai masih diperlukan untuk membantu memudahkan dalam kegiatan pengamatan luas daun di lapangan, terutama untuk mengamati perkembangan luas daun secara kontinu. Pendugaan model matematis luas daun bersifat tidak merusak sampel dan dapat diterapkan secara berkelanjutan pada tanaman yang sama 
tanpa harus bergantung pada alat dan lebih ekonomis menggunakan alat penggaris. Pendekatan model persamaan matematis dari pengukuran daun untuk memprediksi luas daun secara individu maupun keseluruhan daun terbukti sangat bermanfaat dalam mempelajari pertumbuhan dan perkembangan tanaman (Uzun \& Çelik, 1999).

Beberapa peneliti melakukan pendugaan luas daun dengan menggunakan regresi metode Ordinary Least Square (OLS). Lakitan et al. (2017) menganalisis hubungan luas daun pada tanaman buncis dan Uzun \& Çelik (1999) luas daun pada tanaman hortikultura dengan metode OLS. Menurut Petscher \& Logan (2014), analisis regresi OLS merupakan pendugaan hubungan dengan meminimumkan jumlah kuadrat error dan hasil persamaan pendugaan dapat direpresentasikan melalui satu garis regresi. Koenker \& Hallock (2001) menyatakan bahwa metode OLS menggambarkan hubungan sebab akibat berdasarkan distribusi ukuran pemusatan variabel respon sehingga tidak resistan (robust) terhadap kehadiran nilai ekstrim atau pencilan (outlier) pada data. Keberadaan outlier pada data mempengaruhi rata-rata dan standar deviasi sehingga hasil analisis data (pendugaan parameter) kurang tepat. Selain itu, jika varian error antar pengamatan bersifat heterogen (terjadi heteroskedastisitas) atau asumsi homogenitas pada regresi OLS tidak terpenuhi maka model regresi OLS yang terbentuk akan memberikan kesimpulan yang menyesatkan. Metode regresi yang resistan terhadap nilai ekstrim sangat diperlukan sebagai solusi permasalahan regresi OLS.

Regresi kuantil menggambarkan hubungan variabel prediktor terhadap variabel respon pada berbagai kondisi kuantil. Hal ini mampu mengatasi kekurangan dari regresi OLS karena model yang dihasilkan dapat menggambarkan distribusi data secara lebih lengkap. Regresi kuantil menggunakan pendekatan membagi data ke dalam kuantil-kuantil sehingga nilai ekstrim pada data tidak akan mengganggu hasil analisis. Mahmuda et al. (2015) menduga kadar timbal $(\mathrm{Pb})$ dan Siti et al. (2017) memodelkan PDRB di Jawa Timur menggunakan regresi kuantil. Hasil kedua penelitian menyatakan penggunaan regresi kuantil lebih baik dibandingkan regresi OLS melalui nilai R-square yang lebih tinggi. Berdasarkan paparan di atas, penelitian ini bertujuan untuk menduga model pengukuran luas daun tanaman pakcoy (Brassica rapa L.) dengan pendekatan alometrik (panjang dan lebar) dan non destruksi menggunakan regresi kuantil. 


\section{METODE PENELITIAN}

\section{Pengumpulan Data}

Data yang digunakan dalam penelitian merupakan pengukuran panjang, lebar dan luas daun pakcoy yang dibudidayakan di UPT Agrotechnopark Universitas Jember. Pengambilan sampel tanaman dilakukan pada pagi hari di Bulan Juli-Agustus 2020 ketika tanaman berumur 3 minggu. Pemilihan daun-daun secara acak dilakukan guna mendapatkan sampel yang representatif, yaitu dari berbagai level kanopi tanaman pakcoy (lower, middle dan upper). Selanjutnya, dilakukan pemindaian daun dengan scanner (Printer HP Deskjet Ink Advantage 2545). Jumlah sampel daun yang digunakan sebanyak 163 daun.

Lebar daun atau width (W) diukur pada titik terlebar secara tegak lurus dengan tulang tengah daun. Panjang daun atau length (L) diukur dari ujung helaian daun ke titik persimpangan tangkai daun di sepanjang tulang tengah daun. Kedua faktor alometrik tersebut diukur menggunakan penggaris, sedangkan pengukuran luas daun pakcoy dilakukan dengan menggunakan metode gravimetri berdasarkan rumus berikut:

$\mathrm{LA}=\frac{\text { bobot replika daun }}{\text { bobot kertas } 10 \mathrm{~cm} \times 10 \mathrm{~cm}} \times 100 \mathrm{~cm}^{2}(1)$

Data dari hasil pengukuran dibagi 2 kelompok, kelompok pertama merupakan data yang digunakan untuk pemodelan dalam tahap training dan kelompok kedua merupakan data yang digunakan validasi dalam tahap testing. Komposisi data training dan data testing yang digunakan sebesar $70 \%$ dan $30 \%$, yaitu 114 daun sebagai data training dan 49 daun sebagai data testing. Data yang telah terkumpul kemudian diolah dengan menggunakan bantuan software $\mathrm{R}$ studio. Berikut merupakan alur proses pengambilan data, pembuatan model dan aplikasi model untuk pendugaan luas daun pada tanaman pakcoy (Gambar 2).

$\mathrm{L}$

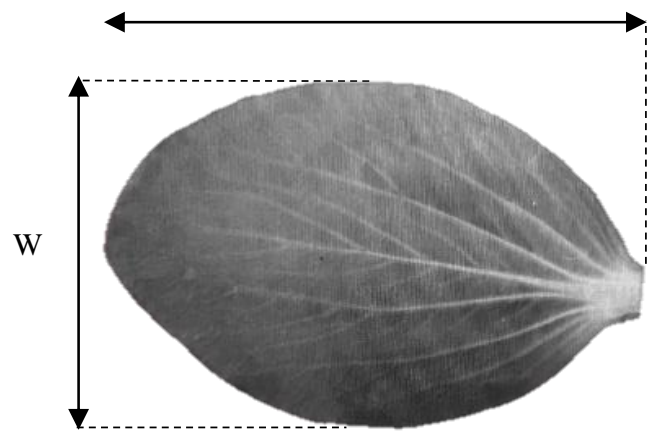

Gambar 1. Pengukuran panjang dan lebar daun Brassica rapa L. 


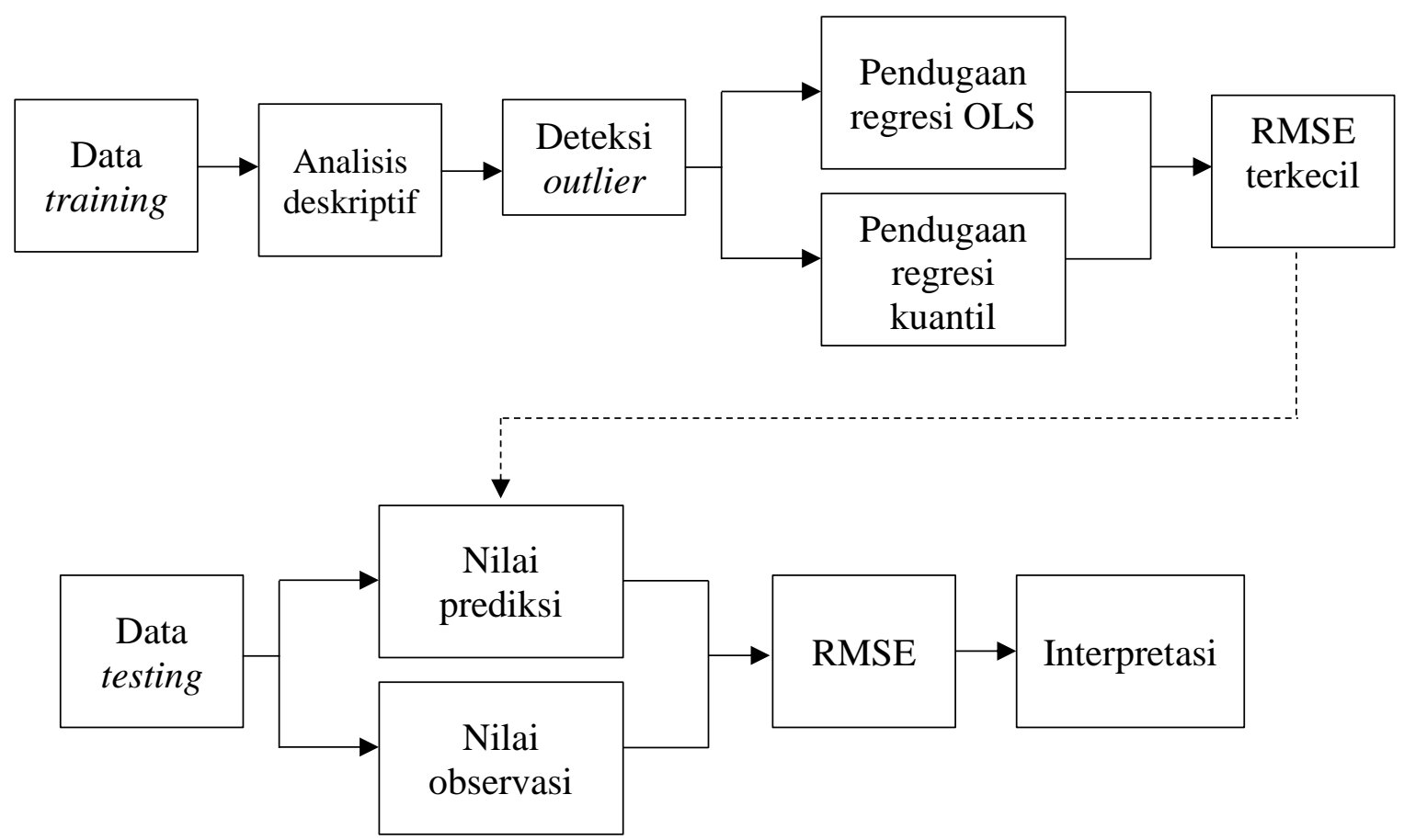

Gambar 2. Diagram alir proses pendugaan model luas daun tanaman pakcoy.

\section{Pendugaan Model Regresi}

Pendugaan model luas daun pada data training dilakukan dengan analisis hubungan antar variabel dengan pendekatan model regresi OLS dan kuantil. Persamaan model regresi kuantil yakni:

$\boldsymbol{y}=\boldsymbol{X} \boldsymbol{\beta}(p)+\boldsymbol{\varepsilon}(p)$

dimana $\quad \boldsymbol{y}=\left[\begin{array}{llll}y_{1} & y_{2} & \ldots & y_{n}\end{array}\right]^{t} ; \quad \boldsymbol{X}=$ $\left[\begin{array}{llll}1 & \boldsymbol{x}_{1} & \ldots & \boldsymbol{x}_{\boldsymbol{k}}\end{array}\right] ; \boldsymbol{\beta}(p)$ adalah vektor parameter pada kuantil ke-p dan $\boldsymbol{\varepsilon}(p)$ adalah vektor error model pada kuantil ke-p. Pendugaan parameter dari persamaan (1) diperoleh dengan meminimumkan jumlah nilai mutlak error dari loss function, sehingga pendugaan diperoleh sebagai berikut:

$\widehat{\boldsymbol{\beta}}(p)=\min _{\beta \in \mathbb{R} p} \sum_{i=1}^{n} \boldsymbol{\rho}_{p}(\boldsymbol{y}-\boldsymbol{X} \boldsymbol{\beta}(p))$

$\operatorname{dimana} \boldsymbol{\rho}_{p}(\boldsymbol{\varepsilon})=\left\{\begin{array}{c}(p-1) \boldsymbol{\varepsilon}, \text { dengan } \boldsymbol{\varepsilon}<0 \\ p \boldsymbol{\varepsilon}, \text { dengan } \boldsymbol{\varepsilon} \geq 0\end{array}\right.$
Luas daun sebagai variabel respon dan variabel prediktor adalah panjang, lebar dan panjang $\times$ lebar. Sebelum analisis, dilakukan identifikasi outlier menggunakan cooks distance dengan rumus:

$D_{i}=\frac{\left(y_{i}-\hat{y}_{i}\right)^{2}}{(k+1) M S E}\left(\frac{h_{i i}}{\left(1-h_{i i}\right)^{2}}\right)$

dimana $h_{i i}$ adalah nilai leverage ke-i dan $\mathrm{k}$ adalah banyaknya variabel prediktor. Pengamatan yang memiliki nilai cooks distance lebih besar dari 4 kali rata-rata didefinisikan sebagai outlier.

\section{Kalibrasi dan Validasi Model}

Kalibrasi dilakukan pada data training untuk memilih kombinasi parameter regresi. Model pendugaan regresi terpilih digunakan untuk memprediksi luas daun dari pengamatan pada kelompok data testing. Validasi model dilakukan pada data testing sampel daun dari berbagai level kanopi 
tanaman yang berbeda (lower, middle dan upper) untuk mengetahui ketepatan prediksi. Kalibrasi dan validasi model dilakukan dengan menggunakan kriteria RMSE minimum yakni (Chai \& Draxler, 2014):

$R M S E=\sqrt{\frac{\sum_{i=1}^{n}\left(y_{i}-\hat{y}_{i}\right)^{2}}{n}}$

\section{HASIL DAN PEMBAHASAN}

\section{Analisis Deskriptif}

Distribusi data sampel pengukuran panjang dan lebar daun pakcoy ditampilkan dalam bentuk boxplot, seperti tertera pada Gambar 3. Hasil persebaran panjang daun pakcoy berkisar antara 3-16 $\mathrm{cm}$ dan lebar daun berkisar antara $2-12 \mathrm{~cm}$. Hal ini menunjukkan bahwa lebar daun memiliki nilai ekstrim, yaitu lebar daun lebih dari 12 cm. Keragaman data lebar daun cenderung relatif seragam dibanding data panjang daun.

Sebagian besar sampel daun pakcoy yang digunakan memiliki luas daun berkisar $40 \mathrm{~cm}^{2}, 50 \mathrm{~cm}^{2}$ dan $60 \mathrm{~cm}^{2}$. Distribusi data luas daun pakcoy hasil pengamatan dapat dilihat pada Gambar. 4, dimana hasil menunjukkan kecenderungan luas daun yang beragam minimal di bawah $20 \mathrm{~cm}^{2}$ dan maksimal di atas $100 \mathrm{~cm}^{2}$.

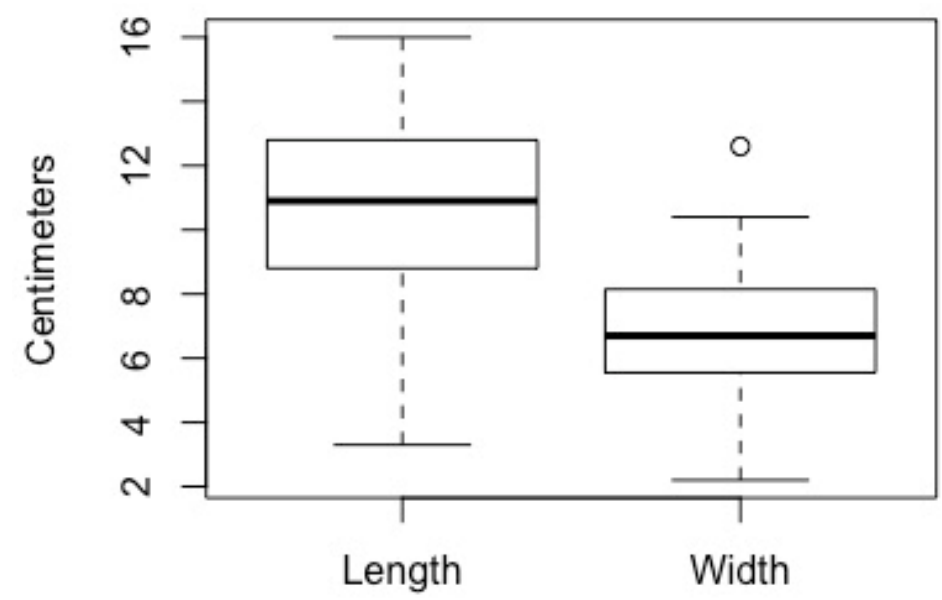

Gambar 3. Boxplot panjang dan lebar daun tanaman pakcoy.

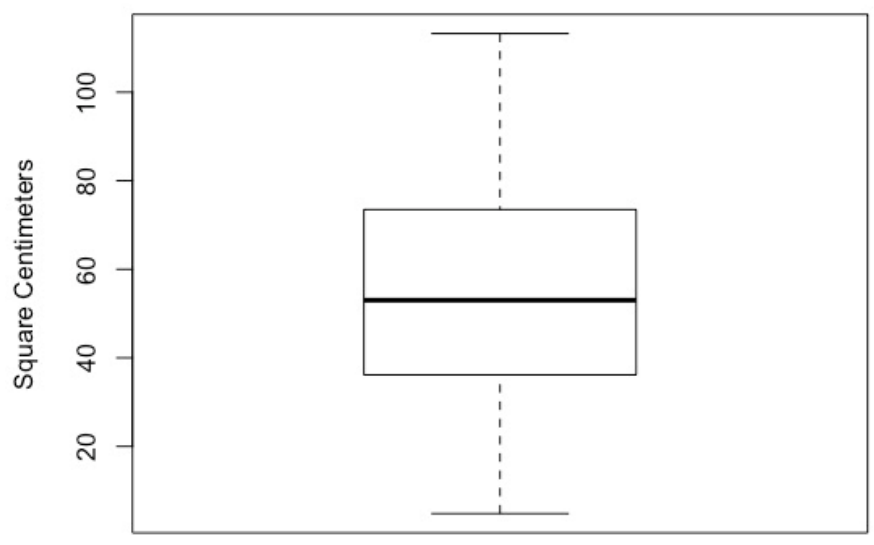

Leaf Area

Gambar 4. Boxplot luas daun tanaman pakcoy. 


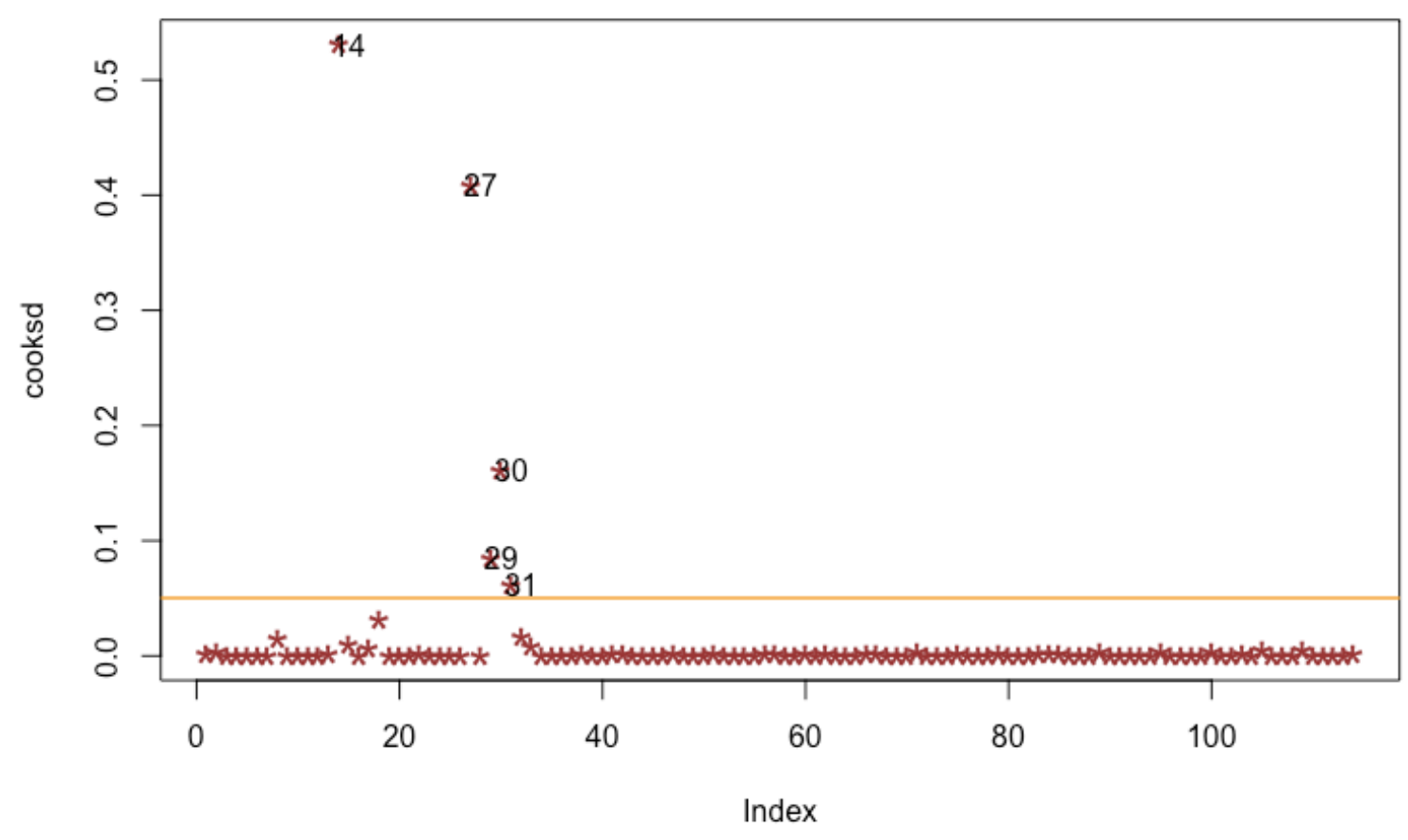

Gambar 5. Scatterplot cook distance faktor alometrik terhadap luas daun.

\section{Pendeteksian Outlier}

Pendeteksian outlier dari data-data luas daun pakcoy yaitu 0,05 (sangat sempit), sampel dilakukan dengan menggunakan scatterplot cook distance faktor alometrik terhadap luas daun, disajikan pada Gambar 5. Plot-plot menunjukkan terdapat lima sampel daun memiliki nilai cook distance lebih dari empat kali rata-rata sehingga sampel 14, 27, 29, 30 dan 31 dikategorikan sebagai outlier. Kondisi ini menjelaskan data penelitian daun Brassica rapa L. mengandung nilai ekstrim.

\section{Pendugaan Model Regresi}

Regresi OLS dan regresi kuantil digunakan dalam memodelkan luas daun. Pendugaan parameter regresi kuantil dilakukan untuk nilai kemungkinan setiap kuantil. Nilai-nilai kuantil merupakan nilai kemungkinan setiap kuantil dalam menjelaskan luas daun pakcoy. Kuantil (p) dalam penelitian ini menunjukkan klasifikasi 0,25 (sempit), 0,50 (sedang), 0,75 (luas) dan 0,95 (sangat luas). Hasil estimasi parameter regresi OLS dan regresi kuantil disajikan pada Tabel 1.

Tabel 1 menunjukkan seluruh parameter koefisien regresi signifikan positif pada taraf signifikansi 0,05 . Hasil pendugaan menggunakan regresi kuantil menunjukkan faktor alometrik cenderung meningkat pada setiap kenaikan antar kuantil. Nilai kuantil semakin besar menunjukkan faktor alometrik semakin besar. Hal ini menjelaskan bahwa pengaruh faktor alometrik semakin besar seiring dengan luas daun yang semakin luas. Pendugaan model dengan nilai kuantil 0,05 menunjukkan analisis dilakukan data luas daun sekitar $4.819 \mathrm{~cm}^{2}$, kuantil 0,25 untuk 
Tabel 1. Estimasi parameter dari model regresi untuk pendugaan luas daun

\begin{tabular}{|c|c|c|c|c|c|c|c|}
\hline \multirow{2}{*}{ Prediktor } & \multirow{2}{*}{ Parameter } & \multicolumn{5}{|c|}{ Kuantil } & \multirow{2}{*}{$\mathrm{OLS}^{1)}$} \\
\hline & & 0.05 & 0.25 & 0.5 & 0.75 & 0.95 & \\
\hline \multirow{3}{*}{$\mathrm{L}$} & $\beta_{0}$ & $-19,116$ & $-24,374$ & $-29,862$ & $-26,908$ & 37,424 & $-21,722$ \\
\hline & $\beta_{1}$ & $5,622^{*}$ & $6,715^{*}$ & $7,745^{*}$ & $8,032^{*}$ & $4,585^{*}$ & $7,190^{*}$ \\
\hline & RMSE & 19,561 & 15,314 & 13,564 & 13,937 & 35,724 & 13,243 \\
\hline \multirow{3}{*}{ W } & $\beta_{0}$ & $-20,783$ & $-32,530$ & $-38,327$ & $-39,518$ & $-25,894$ & $-32,093$ \\
\hline & $\beta_{1}$ & $9,203^{*}$ & $12,048^{*}$ & $13,639^{*}$ & $14,458^{*}$ & $13,961^{*}$ & $12,822^{*}$ \\
\hline & RMSE & 17,056 & 10,983 & 9,527 & 10,407 & 16,742 & 9,369 \\
\hline \multirow{3}{*}{ LW } & $\beta_{0}$ & 0,234 & $-0,368$ & 0,393 & 1,205 & 2,628 & 3,875 \\
\hline & $\beta_{1}$ & $0,632^{*}$ & $0,693^{*}$ & $0,705^{*}$ & $0,717^{*}$ & $0,760^{*}$ & $0,669^{*}$ \\
\hline & RMSE & 10,559 & 8,730 & 8,460 & 8,534 & 10,431 & 8,314 \\
\hline
\end{tabular}

Keterangan: ${ }^{1)}$ OLS merupakan hasil pendugaan regresi OLS, *berpengaruh nyata pada taraf signifikansi $p=0,05$.

luas daun berkisar $34.036 \mathrm{~cm}^{2}$, kuantil 0,5 untuk luas daun berkisar $49.397 \mathrm{~cm}^{2}$, kuantil 0,75 untuk luas daun berkisar $69.879 \mathrm{~cm}^{2}$ dan kuantil 0,95 untuk luas daun berkisar 113.253 $\mathrm{cm}^{2}$.

\section{Kalibrasi Model}

Nilai RMSE digunakan untuk membandingkan performa model regresi berdasarkan variabel prediktor dan jenis regresi yang digunakan. Nilai RMSE semakin kecil (mendekati nol) maka semakin tinggi tingkat akurasi prediksi luas daun. Model pendugaan regresi menggunakan variabel prediktor L dan $\mathrm{W}$ memberikan hasil RMSE cenderung lebih besar dibandingkan dengan model pendugaan regresi dengan variabel prediktor LW. Tabel 1 memberikan kesimpulan model regresi menggunakan variabel prediktor L dan $\mathrm{W}$ kurang sesuai digunakan dalam mengestimasi luas daun pakcoy. Hasil penelitian ini sejalan dengan Cristofori et al. (2007) dan Lakitan et al. (2017) yang menyatakan LW sebagai variabel prediktor lebih akurat digunakan dalam mengestimasi luas daun.

\section{Validasi Model}

Berikut perbandingan nilai prediksi dan nilai observasi dari kelompok data testing dengan menggunakan model pendugaan regresi OLS dan regresi kuantil dengan menggunakan variabel prediktor LW.

Gambar 6. menunjukkan grafik perbandingan nilai prediksi dari luas daun (kurva merah) dan nilai observasi (kurva hitam) dengan menggunakan model regresi kuantil dan OLS. Kurva merah pada Gambar 5A dan 5E tidak tumpang tindih (overlapping) dengan kurva hitam. Hal ini menunjukkan model regresi kuantil 0.05 dan kuantil 0.95 kurang tepat untuk melakukan prediksi atau memiliki akurasi rendah dalam memprediksi luas daun pakcoy. Kurva merah dan kurva hitam pada Gambar 5B; 5C; 5D dan 5F terlihat saling tumpang tindih (fit) sehingga model pendugaan luas daun dengan menggunakan model regresi kuantil 0,25, 
p-ISSN: 1410-0029; e-ISSN2549-6786

Agrin Vol. 25, No. 1, April 2021

regresi kuantil 0,5 dan regresi OLS mampu

yang relatif kecil dibandingkan model menjelaskan dengan baik kelompok data pendugaan OLS. Model yang testing. Nilai RMSE minimum diantara ketiga direkomendasikan menjelaskan bahwa setiap model tersebut yaitu 10.031 pada model pertambahan faktor alometrik sebesar $1 \mathrm{~cm}^{2}$ regresi kuantil 0,5 yaitu $\mathrm{LA}_{0.5}=0,393+$ atau kenaikan $1 \mathrm{~cm}^{2}$ dari panjang $\times$ lebar daun 0.705LW. Model tersebut memiliki akurasi akan mengakibatkan pertambahan luas daun prediksi lebih tinggi atau tingkat kesalahan sebesar $0,7 \mathrm{~cm}^{2}$.

A

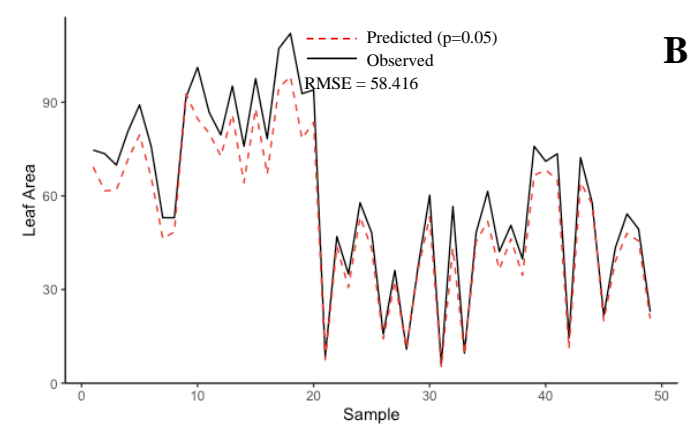

$\mathbf{C}$

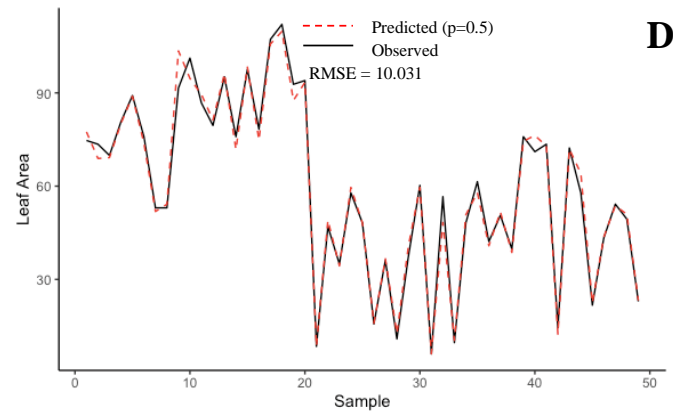

$\mathbf{E}$

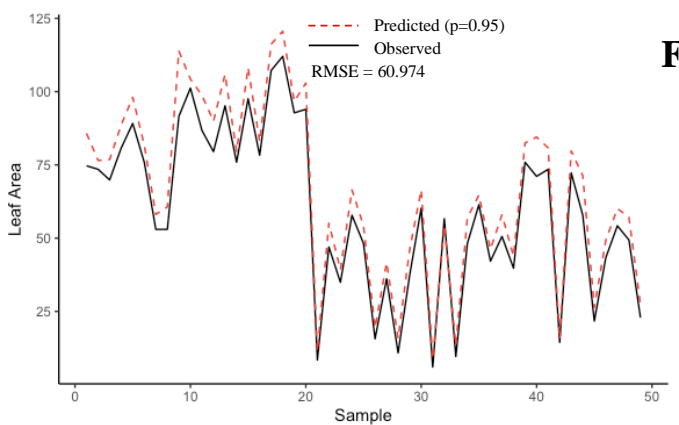

B

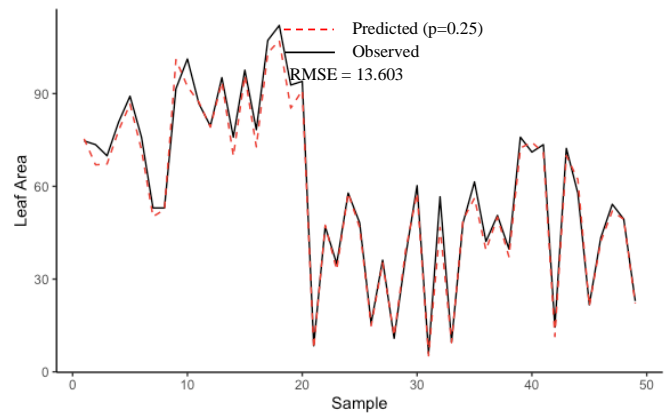

D

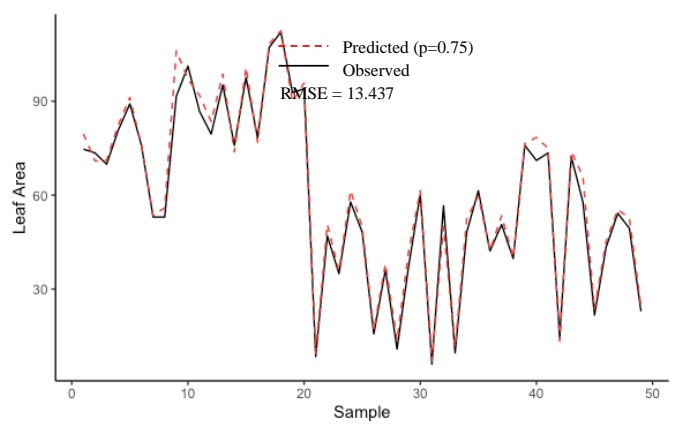

$\mathbf{F}$

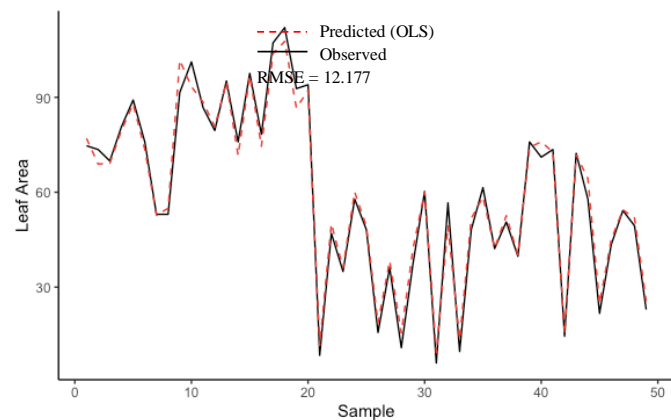

Gambar 6. Grafik nilai prediksi dan nilai observasi dari model regresi kuantil 0,05 (A), kuantil 0,25 (B), kuantil 0,5 (C), kuantil 0,75 (D), kuantil 0,95 (E) dan regresi OLS (F) 


\section{KESIMPULAN}

Model regresi kuantil dapat digunakan untuk memprediksi luas daun pakcoy secara non destruksi dan cepat dengan ketepatan akurasi tinggi. Interval yang dihasilkan dari model regresi kuantil 0,05 hingga regresi kuantil 0,95 dapat digunakan sebagai kisaran luas daun pada berbagai ukuran level kanopi tanaman pakcoy. Model estimasi luas daun pakcoy yang direkomendasikan yakni $\mathrm{LA}_{0,5}=$ $0,393+0,705 \mathrm{LW}$.

\section{DAFTAR PUSTAKA}

Andreeilee, B. F., Santoso, M., \& Nugroho, A. (2014). Pengaruh jenis kompos kotoran ternak dan waktu penyiangan terhadap produksi tanaman pakcoy (Brassica rapa sub. chienensis) organik. Jurnal Produksi Tanaman, 2(3), 190-197.

Astuti, S., \& Larasati, W. A. (2019). Respon tanaman sawi pakcoy (Brassica rapa) terhadap larutan hara (kotoran ikan) pada sistem akuaponik. Konservasi Hayati, 10(1), 10-15. https:// doi.org/10.33369/hayati.v1i1.10942

Chai, T., \& Draxler, R. R. (2014). Root Mean Square Error (RMSE) or Mean Absolute Error (MAE): Arguments against avoiding RMSE in the literature. Geoscientific Model Development, 7(3), 1247-1250. https://doi.org/10.5194/gmd-7-12472014

Cristofori, V., Rouphael, Y., Gyves, E. M. de, \& Bignami, C. (2007). A simple model for estimating leaf area of hazelnut from linear measurements. Scientia Horticulturae, 113(2), 221225. https://doi.org/10.1016/j.scienta. 2007.02.006
Irwan, A. W., \& Wicaksono, F. Y. (2017). Perbandingan pengukuran luas daun kedelai dengan metode gravimetri, regresi dan scanner Comparations of soybean's leaf area measurement using gravimetry, regression, and scanning. Jurnal Kultivasi, 16(3), 425-429. https://doi.org/10.24198/ kultivasi.v16i3.14448

Kaur, G., Din, S., Singh Brar, A., \& Singh, D. (2014). Scanner image analysis to estimate leaf area. International Journal of Computer Applications, 107(3), 5-10. https://doi.org/10.5120 /18729-9963

Koenker, R., \& Hallock, K. F. (2001). Quantile regression. Journal of Economic Perspectives, 15(4), 143156. https://doi.org/10.1038/s41592019-0406-y

Lakitan, B., Widuri, L. I., \& Meihana, M. (2017). Simplifying procedure for a non-destructive, inexpensive, yet accurate trifoliate leaf area estimation in snap bean (Phaseolus vulgaris). Journal of Applied Horticulture, 19(1), 15-21. https://doi.org/ 10.37855/jah.2017.v19i01.03

Mahmuda, L. N., Nur, I. M., \& Karim, A. (2015). Regresi kuantil sebagai penduga kadar timbal $(\mathrm{Pb})$ dalam tubuh pekerja SPBU di kota semarang. Jurnal Statistika Universitas Muhammadiyah Semarang, 3(2), 25-28.

Petscher, Y., \& Logan, J. A. R. (2014). Quantile regression in the study of developmental sciences. Child Development, 85(3), 861-881. https://doi.org/10.1111/cdev.12190

Rahmadhani, L. E., Widuri, L. I., \& Dewanti, P. (2020). Kualitas mutu sayur kasepak (kangkung, selada, dan pakcoy) dengan sistem budidaya akuaponik dan hidroponik. Jurnal Agroteknologi, 14(1), 33-34. https://doi.org/10.19184/j-agt.v14i01 .15481 
Rizal, S. (2017). Pengaruh nutrisi yang diberikan terhadap pertumbuhan tanaman sawi pakcoy (Brassica rapa L.) yang ditanam secara hidroponik. Sainmatika, 14(1), 38-44.

Rubatzky, V. E., \& Yamaguchi. (1997). World Vegetables: Principle, Production and Nutritiev Values (California (ed.)). Springer Science Business Media, BV.

Sadik, S. K., Al-Taweel, A. A., Dhyeab, N. S., \& Khalaf, M. Z. (2011). New computer program for estimating leaf area of siveral vegetable crops. American-Eurasian Journal of Sustainable Agriculture, 5(2), 304309.

Santoso, A., Widyawati, N., \& Diponegoro, J. (2020). Pengaruh umur bibit terhadap pertumbuhan dan hasil pakcoy (Brassica rapa ssp. chinensis) pada hidroponik NFT. Vegetalika, 9(3), 464-473. https://doi.org/ 10.22146/veg.52570

Siti, M., Nur, I. M., \& Karim, A. (2017). Pemodelan produk domestik regional bruto (PDRB) di provinsi jawa tengah menggunakan regsresi kuantil. Jurnal Statistika, 5(1), 52-59.
Sobari, E., Ferdi Fathurohman, \& Hadi, M. A. (2018). Karakter pertumbuhan kacang tanah (Arachis hypogaea L.) dengan pemanfaatan kompos limbah baglog jamur dan kotoran domba. Agrin, 22(2), 116-122. https:// doi.org/10.20884/1.agrin.2018.22.2. 447

Uzun, S., \& Çelik, H. (1999). Leaf area prediction models (Uzçelik-I) for different horticultural plants. Turkish Journal of Agriculture and Forestry, 23(6), 645-650. https://doi.org/ 10.3906/tar-98124

Wibowo, S., \& Asriyanti, A. (2013). Aplikasi hidroponik NFT pada budidaya pakcoy (Brassica rapa chinensis). Jurnal Penelitian Pertanian Terapan, 13(3), 159-167.

Yan, G., Hu, R., Luo, J., Weiss, M., Jiang, H., Mu, X., Xie, D., \& Zhang, W. (2019). Review of indirect optical measurements of leaf area index: Recent advances, challenges, and perspectives. Agricultural and Forest Meteorology, 265(March 2018), 390411.https://doi.org/10.1016/j.agrform et.2018.11.033 